\title{
SISTEM PENALARAN BERBASIS KASUS UNTUK PENDUKUNG DIAGNOSIS GANGGUAN PENYAKIT PADA UNGGAS (Case Based Reasoning System to Support Diagnosis of Diseases in Poultry)
}

\author{
Murien Nugraheni $^{1)}$,Sri Hartati ${ }^{2)}$ \\ ${ }^{1,2)}$ Program Studi Ilmu Komputer \\ Program Pascasarjana Universitas Gadjah Mada \\ Sekip Utara, Bulaksumur, Yogyakarta 55281 Indonesia \\ e-mail: murien_n@yahoo.com ${ }^{1}$, shartati@ugm.ac.id ${ }^{2}$
}

\begin{abstract}
ABSTRAK
Case-Based Reasoning (CBR) merupakan sistem penalaran komputer yang menggunakan pengetahuan lama untuk mangatasi permasalahan baru. CBR memberikan solusi terhadap kasus baru dengan melihat kasus lama yang paling mendekati kasus baru. Hal ini akan sangat bermanfaat karena dapat menghilangkan kebutuhan untuk mengekstrak model seperti yang dibutuhkan oleh sistem berbasis aturan. Selain itu, CBR juga dapat dimulai dari jumlah pengetahuan yang sedikit, karena pengetahuan CBR dapat bertambah secara bertahap ketika sebuah kasus ditambahkan.

Penelitian ini mencoba untuk membangun suatu Sistem Penalaran Berbasis Kasus untuk Mendukung Diagnosa Gangguan Penyakit pada Unggas dengan melihat ciri-ciri gejala yang terlihat pada unggas. Proses diagnosa dilakukan dengan cara memasukkan kasus baru yang berisi gejala-gejala yang akan didiagnosa ke dalam sistem, kemudian sistem akan melakukan proses indexing atau pengelompokkan dengan menggunakan Algoritma C4.5 untuk memperoleh indeks dari kasus baru tersebut. Setelah memperoleh indeks dari kasus, sistem selanjutnya melakukan proses perhitungan similarity antara kasus baru dengan basis kasus yang memiliki indeks yang sama dengan kasus baru menggunakan metode Cosine Similarity. Kasus yang diambil adalah kasus dengan similarity yang paling tinggi. Jika suatu kasus tidak berhasil didiagnosa, maka akan dilakukan revisi kasus oleh pakar. Kasus yang berhasil direvisi akan disimpan ke dalam sistem untuk dijadikan pengetahuan baru bagi sistem.

Hasil penelitian menunjukkan sistem penalaran berbasis kasus untuk mendiagnosa penyakit pada unggas ini membantu pakar dan peternak dalam melakukan diagnosa. Hasil pengujian sistem terhadap 30 kasus uji, sistem telah mampu menghasilkan kemiripan sebanyak 28 kasus (93.33\%) dan diperoleh 2 kasus (6.67\%) yang memiliki nilai similarity di bawah 0.8 yang akan dilakukan revisi oleh pakar.
\end{abstract}

Kata kunci : CBR, unggas, indexing, similarity, cosine similarity

\begin{abstract}
Case-Based Reasoning (CBR) is a computer system that uses old knowledge to solve new problems. CBR provide solutions for new cases by looking at an old case that comes closest to the new case. It will be very useful because it eliminates the need to extract the model as required by the rules-based system. Moreover, CBR can also be started from a small amount of knowledge, because the knowledge of CBR can be increased gradually when a case is added.

This study tries to establish a system for Case-Based Reasoning System to Support Diagnosis of Diseases in Poultry by looking at the characteristics of existing symptoms in poultry. Diagnosis process is done by inserting a new cases that contain the symptoms of the disease to be diagnosed into the system, then the system will do the indexing process or classification with C4.5 algorithm method to obtain an index of new cases. After obtaining an index of the cases, then the system do the calculating of the value of similarity between the new case by case which has the same index with new cases using Cosine Similarity method. The case taken is the case with the highest similarity value. If a case is not successfully diagnosed, then the case will be revised by experts. Revised successful cases will be stored into the system to be used as new knowledge for the system.

The results showed case-based reasoning system to diagnose disease of poultry can help experts and farmers in performing diagnostics. The test results of 30 test cases, system has been to produce similarity of 28 cases (93.33\%) and obtained 2 cases (6.67\%) have similarity values below 0.8 will be revised by experts.
\end{abstract}

Keywords: $C B R$, poultry, indexing, similarity, cosine similarity 


\section{PENDAHULUAN}

U nggas merupakan hewan ternak yang paling banyak diternakkan karena banyak memberikan manfaat dan keuntungan. Baik untuk dikonsumsi maupun sekedar untuk dipelihara. Sebagaimana dengan hewan ternak lain, unggas mempunyai bermacam jenis penyakit.

Ada banyak jenis penyebab penyakit yang menyerang ayam, antara lain yang disebabkan oleh virus, bakteri, protozoa, maupun jamur. Salah satu penyakit pada ayam yang disebabkan oleh virus adalah Avian Influenza atau yang sering disebut sebagai flu burung. Berdasarkan laporan tim Technical Support Medion diketahui bahwa sejak tahun 2012 hingga 2014, total kasus Avian Influenza yang menyerang peternakan ayam pedaging dan petelur menunjukkan tren peningkatan yang cukup signifikan [1].

Kemampuan manusia yang coba ditiru oleh para ahli adalah kemampuan dalam menyelesaikan masalah berdasarkan kejadian-kejadian yang telah terjadi sebelumnya. Pada umumnya, manusia menyelesaikan permasalahan yang dihadapi berdasarkan pengalaman-pengalaman yang telah dimiliki, ataupun berdasarkan pengalaman dari orang lain. Hal inilah yang ditiru oleh ahli komputer, sehingga menghasilkan suatu sistem yang dikenal dengan penalaran berbasis kasus atau Case-based Reasoning (CBR).

Proses pengelompokkan data menggunakan metode Algoritma C4.5 yang merupakan algoritma untuk membentuk suatu pohon keputusan. Menurut [2] algoritma C4.5 merupakan struktur pohon yang dapat digunakan untuk membagi kumpulan data yang besar menjadi himpunan-himpunan record yang lebih kecil dengan menerapkan serangkaian aturan keputusan. Pemilihan atribut pada algoritma ini dilakukan berdasarkan pada ukuran entropy yang dikenal dengan information gain sebagai sebuah cara untuk memilih atribut yang terbaik dengan nilai tertinggi dari nilai kedalam kelas.

Proses mencari kedekatan atau kemiripan antara kasus baru dengan kasus lama untuk memperoleh solusi terhadap kasus baru pada CBR dapat menggunakan berbagai macam metode, dimana metode ini akan mempengaruhi keberhasilan dari CBR. Salah satu metode yang dapat digunakan dalam mencari kedekatan atau kemiripan kasus baru dengan kasus lama adalah Cosine Similarity. Metode ini mengkorelasikan dua objek variabel kontinue yang mempunyai hubungan liniear diantara atribut pada suatu objek.

\section{METODE}

\section{A. Case-Based Reasoning}

Case-based Reasoning (CBR) merupakan suatu teknik pemecahan masalah, yang mengadopsi solusi masalahmasalah sebelumnya yang mirip dengan masalah baru yang dihadapi, untuk mendapatkan solusi [3]. CBR menitikberatkan pemecahan masalah dengan didasarkan pada knowledge dari kasus-kasus sebelumnya, apabila ada kasus baru maka akan disimpan pada basis pengetahuan sehingga sistem akan melakukan learning dan knowledge yang dimiliki oleh sistem akan bertambah.

\section{B. Pohon Keputusan}

Sebuah pohon keputusan aalah sebuah struktur yang dapat digunakan untuk membagi kumpulan data yang besar menjadi himpunan-himpunan record yang lebih kecil dengan menerapkan serangkaian keputusan [4].

\section{Algoritma C4.5}

Algoritma C4.5 yaitu sebuah algoritma yang digunakan untuk membangun decision tree (pengambilan keputusan). Algoritma C4.5 adalah salah satu algoritma induksi pohon keputusan yaitu ID3 (Iterative Dichotomiser 3). ID3 dikembangkan oleh J. Ross Quinlan. Dalam prosedur algoritma ID3, input berupa sampel training, label training dan atribut. Algoritma C4.5 merupakan pengembangan dari ID3. Pohon dibangun dengan cara membagi data secara rekursif hingga tiap bagian terdiri dari data yang berasal dari kelas yang sama. Bentuk pemecahan (split) yang digunakan untuk membagi data tergantung dari jenis atribut yang digunakan dalam split.

Untuk memilih atribut sebagai akar, didasarkan pada nilai gain tertinggi dari atribut-atribut yang ada. Untuk menghitung gain digunakan rumus seperti tertera dalam persamaan di bawah ini :

$$
\operatorname{Gain}(S, A)=\operatorname{Entropy}(S)-\sum_{i=1}^{n} \frac{\left|S_{i}\right|}{|S|} * \operatorname{Entropy}\left(S_{i}\right)
$$

Keterangan:

$S \quad$ : Himpunan kasus

A : Atribut

$n \quad:$ Jumlah partisi A

$|S i|$ : Jumlah kasus pada partisi ke i

$|S|$ : Jumlah kasus dalam $S$

Sedangkan perhitungan nilai entropy dapat dilihat pada persamaan berikut: 
$\operatorname{Entropy}(S)=\sum_{i=1}^{n}-p_{i} * \log _{2} p_{i}^{\sum_{\mathrm{i}-1}^{\mathrm{n}}-\mathrm{pi}^{*} \log _{2} \mathrm{pi}}$

Keterangan :

$S \quad$ : Himpunan kasus

$n \quad$ : jumlah partisi $S$

pi : Proporsi Si terhadap $S$

Pada penelitian ini metode yang digunakan untuk indexing adalah Algoritma C4.5. Algoritma C4.5 adalah sebagai berikut : [5]

1. Pilih atribut sebagai akar berdasarkan nilai gain tertinggi

2. Buat cabang untuk masing-masing nilai

3. Bagi kasus dalam cabang

Ulangi proses untuk masing-masing cabang sampai semua kasus pada cabang memiliki kelas yang sama.

\section{Cosine Similarity}

Cosine Similarity adalah salah satu metode similaritas yang digunakan untuk melakukan perhitungan tingkat kemiripan dari dua buah objek.

Jika x dan y adalah dua buah vektor, [6] mendefinisikan Cosine Similarity sebagai berikut :

$$
\begin{aligned}
\mathrm{EJ}(\mathrm{x}, \mathrm{y})= & \frac{\mathrm{x} \cdot \mathrm{y}}{\|\mathrm{x}\| 2+|| \mathrm{y}|| 2-\mathrm{x} \cdot \mathrm{y}} \cos (x, y)=\frac{x \cdot y}{\|x\|\|y\|} \\
& \text { dimana . menunjukkan vektor dot produk, } x \cdot y=\sum_{k=1}^{n} x_{k} y_{k} \text { dan }\|\| \text { menunjukkan norm. }
\end{aligned}
$$

\section{A. Diagram Konteks}

Gambar 1 merupakan diagram konteks yang menggambarkan tingkat tertinggi dari sistem secara keseluruhan.

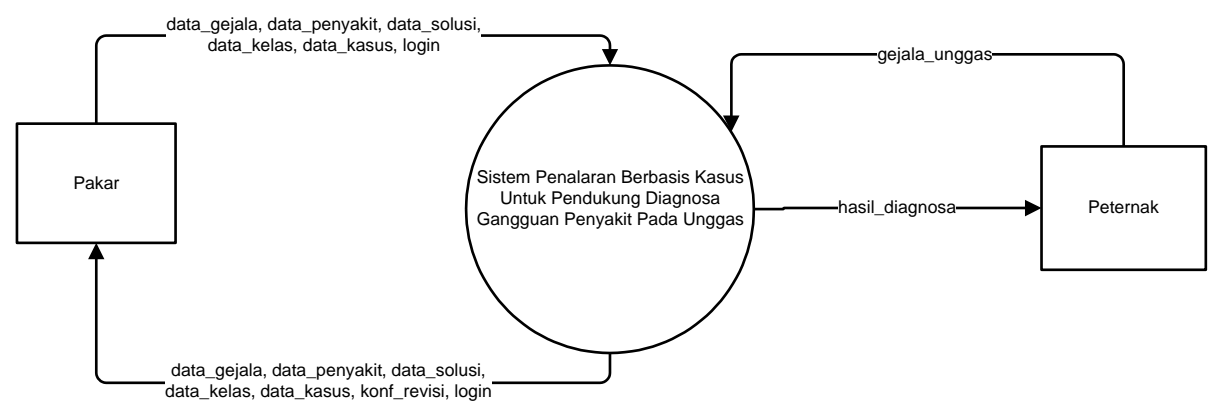

Gambar 1. Diagram Konteks Sistem Penalaran Berbasis Kasus Untuk Pendukung Diagnosa Gangguan Penyakit Pada Unggas

Diagram konteks terdiri dari dua elemen lingkungan yaitu Pakar dan Peternak serta sebuah proses secara keseluruhan dari sistem case-based reasoning untuk mendiagnosa penyakit unggas. Pakar akan memberikan input ke sistem berupa data gejala, data penyakit, data solusi, data kelas, data kasus untuk case base serta melakukan revisi dari suatu kasus. Data gejala dan data penyakit merupakan data-data master yang diperlukan oleh sistem untuk bekerja. Peternak akan memberikan input ke sistem berupa kasus baru, dimana kasus tersebut berisi gejalagejala penyakit dan akan dilakukan diagnosa penyakit yang dialami oleh unggasnya. Jika kasus tersebut berhasil didiagnosa, maka peternak akan menerima hasil diagnosa untuk penyakit unggasnya. Apabila kasus baru tidak berhasil didiagnosa, maka proses revisi akan dilakukan oleh Pakar, dan hasil dari revisi akan disimpan sebagai basis kasus.

\section{B. Rancangan Basis Data}

Berdasarkan proses yang tergambar dalam rancangan DFD maka diperoleh gambaran tentang rancangan basis data dalam sistem yang dibangun. Gambar 2 menggambarkan tentang rancangan basis data sistem dalam bentuk ERD.

Berdasarkan Gambar 2 maka sistem penalaran berbasis kasus untuk diagnosa penyakit pada unggas ini terdapat beberapa aturan, yaitu :

1. Setiap kasus memiliki satu penyakit

2. Satu penyakit dapat digunakan oleh beberapa kasus 
3. Setiap kasus memiliki satu kelas

4. Satu kelas dapat digunakan oleh beberapa kasus

5. Setiap gejala memiliki satu penyakit

6. Satu penyakit dapat digunakan oleh beberapa gejala

7. Setiap gejala memiliki satu kasus

8. Satu kasus dapat digunakan oleh beberapa gejala

9. Setiap kasus memiliki satu solusi

10. Satu solusi dapat digunakan oleh beberapa kasus

11. Setiap penyakit memiliki satu solusi

12. Satu solusi dapat digunakan oleh beberapa penyakit

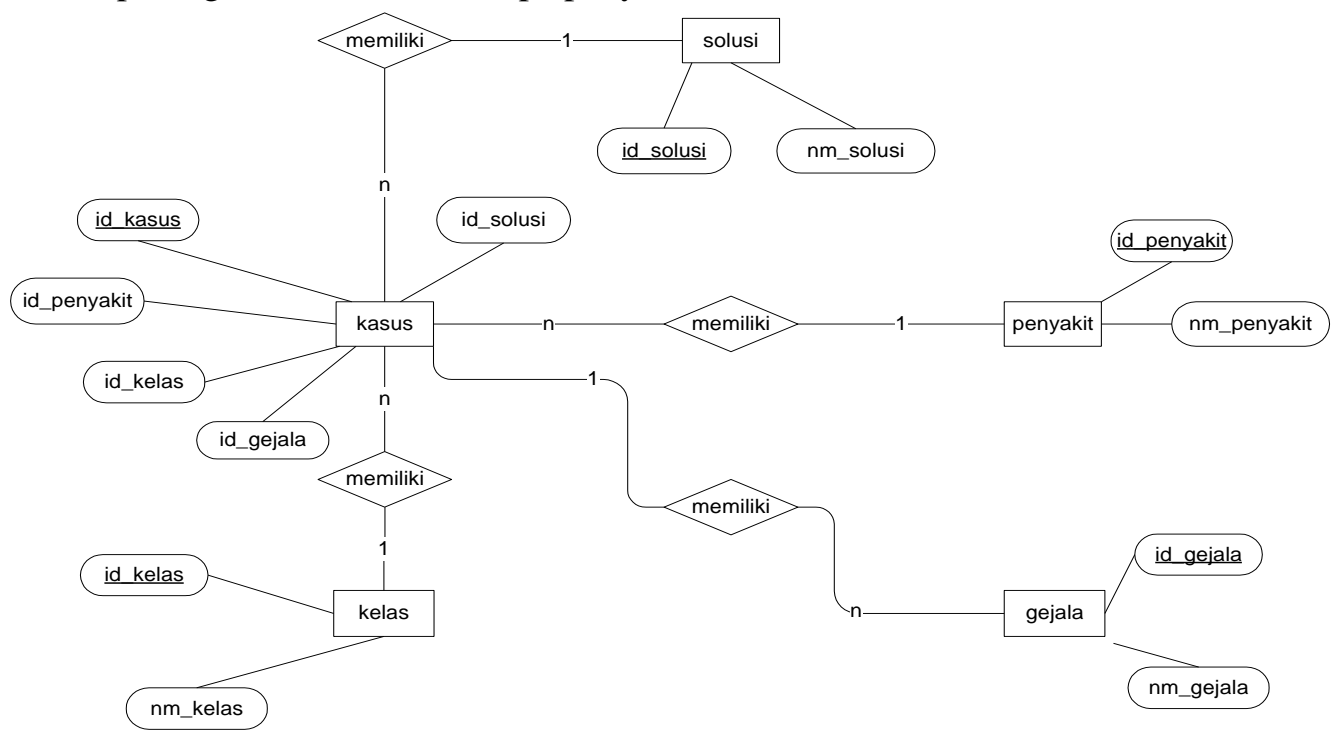

Gambar 2. Entity Relationship Diagram

\section{A. Form Menu Utama}

Ketika sistem mulai dieksekusi, maka akan muncul tampilan form utama dari sistem seperti tampak pada Gambar 3. Menu dari sistem yang dapat diakses hanya terbatas pada menu login, menu pohon keputusan, menu diagnosa, dan menu help. Sedangkan menu untuk pengolahan data hanya dapat diakses oleh seorang pakar setelah melakukan login.

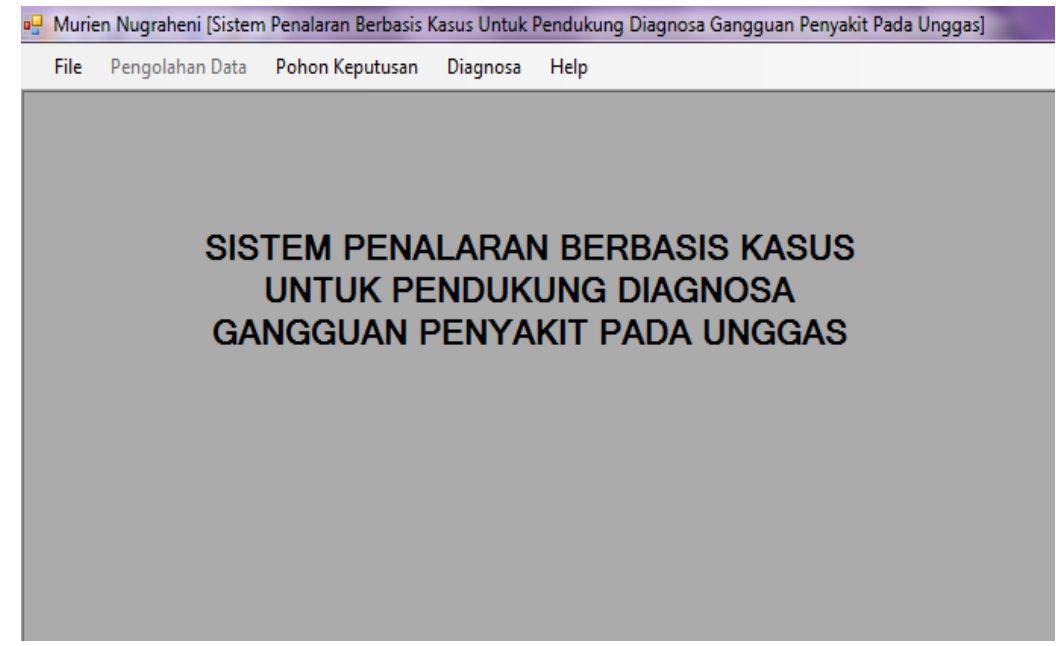

Gambar 3. Form Menu Utama

Pakar perlu melakukan login agar dapat mengakses menu pengolahan data sedangkan untuk peternak tidak perlu melakukan login, karena peternak hanya dapat mengakses menu diagnosa.

\section{B. Form Pohon Keputusan}

Gambar 4 menampilkan proses perhitungan indexing menggunakan Algoritma C4.5 yang menghasilkan pohon keputusan. Sedangkan Gambar 5 menampilkan pohon keputusan. 


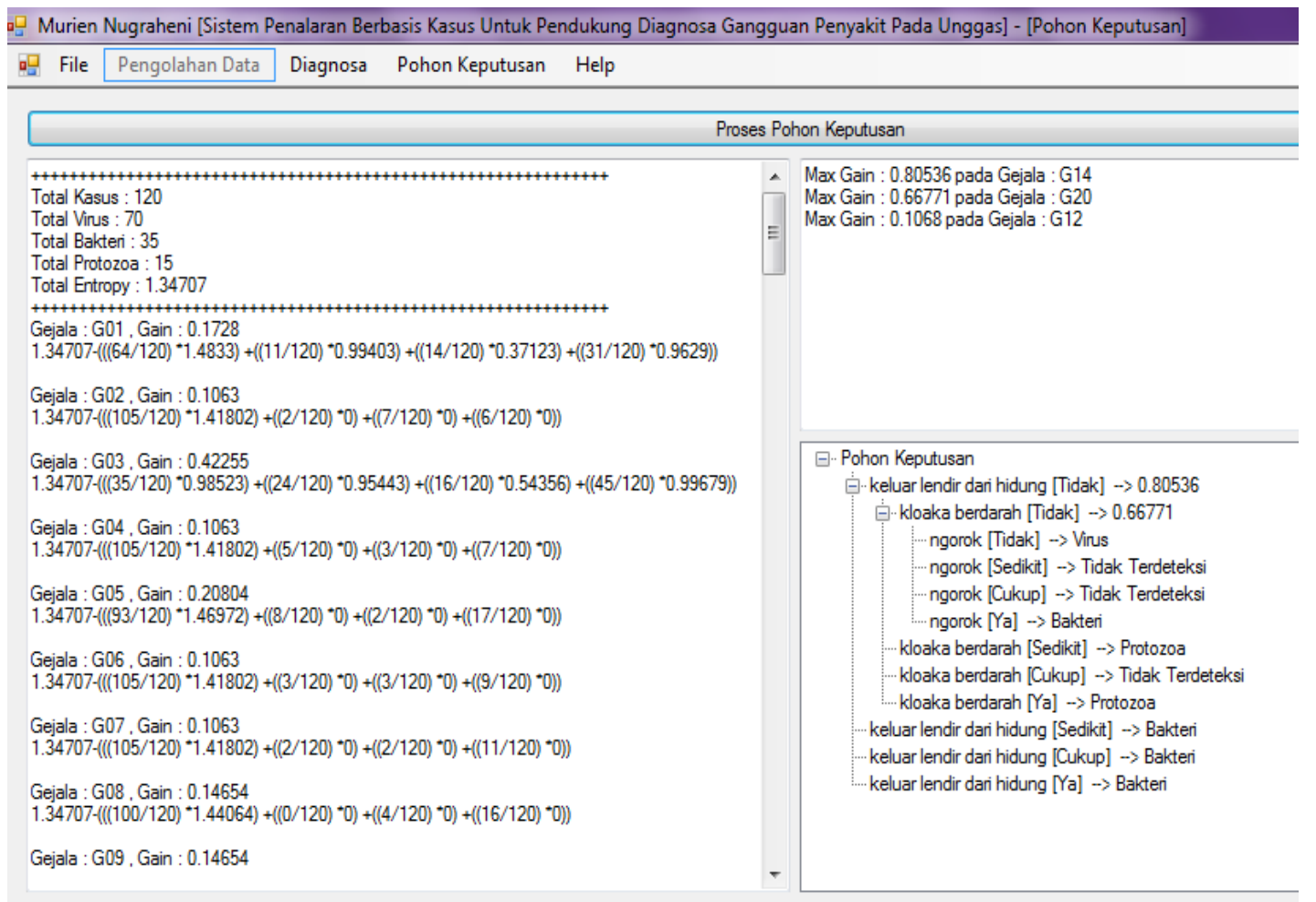

Gambar 4. Form Pohon Keputusan

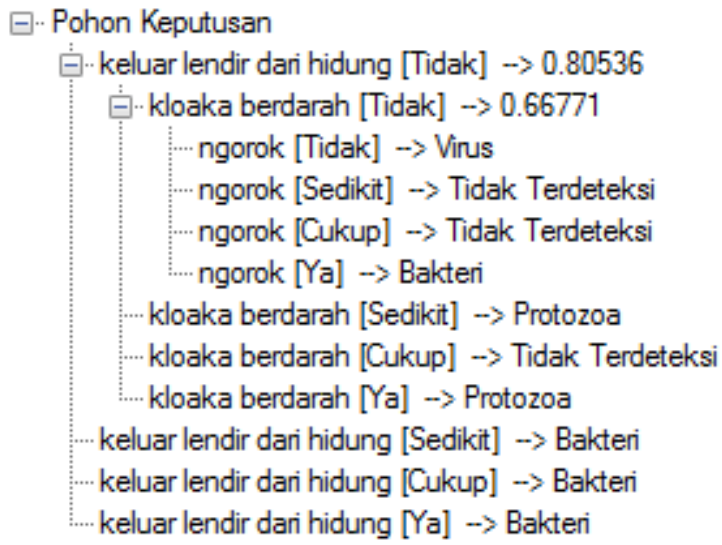

\section{Form Diagnosa Kasus Baru}

\section{Gambar 5. Hasil Pohon Keputusan}

Proses diagnosa kasus baru dilakukan oleh pakar dan peternak, ketika ada unggas yang mengalami gejala suatu penyakit. Form proses diagnosa kasus baru dapat dilihat pada Gambar 6. Proses awal dalam melakukan proses diagnosa adalah memasukkan gejala-gejala yang dialami oleh unggas tersebut. Hasil dari diagnosa kasus baru dapat dilihat pada Gambar 7.

\begin{tabular}{|c|c|c|c|c|}
\hline \multicolumn{2}{|c|}{$\square$ Form Diagnosa } & \multicolumn{3}{|c|}{$\square$ 回 $x$} \\
\hline & id_gejala nm_gejala & \multicolumn{2}{|c|}{ Pilih Atribut } & A \\
\hline G01 & Produksi telur menurun & cukup & $\checkmark$ & \\
\hline G02 & Kualitas telur menurun & tidak & $\checkmark$ & $\equiv$ \\
\hline G03 & Gangguan pemafasan & ya & $\checkmark$ & \\
\hline G04 & Diare & tidak & $\checkmark$ & \\
\hline G05 & Lesu, lemas, murung & tidak & $\checkmark$ & \\
\hline G06 & Jengger pucat & tidak & $\checkmark$ & \\
\hline G07 & Kaki merah-merah & tidak & $\checkmark$ & \\
\hline
\end{tabular}

Gambar 6. Form Diagnosa Kasus Baru 


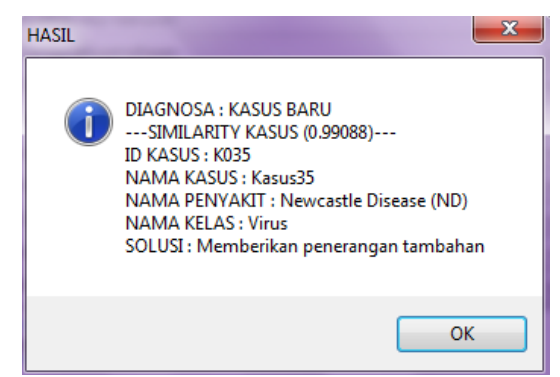

Gambar 7. Hasil Diagnosa Kasus Baru

Proses diagnosa diawali dengan proses pembuatan kelas pada pohon keputusan. Kemudian dilakukan proses similaritas yang berada hanya pada kelas yang sama, yang didapat dari pohon keputusan.

\section{HASIL DAN PEMBAHASAN}

Proses pengujian sistem diagnosa penyakit pada unggas menggunakan CBR dilakukan dengan dua cara yaitu pengujian yang dilakukan pakar dan pengujian sistem dengan menggunakan sampel data kasus.

Pada pengujian sistem menggunakan sample data kasus digunakan Algoritma C4.5 sebagai proses indexing dan Cosine Similarity sebagai proses untuk mencari nilai similaritynya.

\section{A. Pengujian Sistem oleh Pakar}

Pada bagian ini akan dilakukan pengujian kasus riil terhadap sistem. Kasus yang akan diuji memiliki gejala sebagai berikut :

1. Produksi telur menurun : cukup

2. Kualitas telur menurun : tidak

3. Gangguan pernafasan : ya

4. Diare : tidak

5. Lesu, lemas, murung : tidak

6. Jengger pucat : tidak

7. Kaki merah-merah : tidak

8. Gangguan syaraf/ tubuh gemetar : ya

9. Kaki lumpuh : cukup

10.Berkumpul pada tempat hangat : ya

11.Berjalan berputar-putar : ya

12.Ngorok : tidak

13.Nafsu makan menurun : tidak

14.Keluar lendir dari hidung : tidak

15. Mata berair : tidak

16.Gangguan pertumbuhan : tidak

17.Muka dan jengger bengkak : tidak

18.Pilek : tidak

19.Menggigil : tidak

20.Kloaka berdarah : tidak

21.Diare putih : tidak

22.Bulu pucat : tidak

23. Anus lengket : tidak

24. Mematoki dubur sendiri : tidak

25. Anus berdarah : tidak

26. Diare berdarah : tidak 
Berdasarkan data yang dimasukkan pakar, pakar berkesimpulan bahwa unggas tersebut menderita Newcastle Disease yang disebabkan oleh virus. Setelah dilakukan proses diagnosa menggunakan sistem, sistem memberikan hasil bahwa penyakit yang dimiliki unggas adalah Newcastle Disease dengan nilai similaritas 0.9988 pada kasus ke 35. Adapun tampilan hasil diagnosa kasus tersebut dapat dilihat pada Gambar 4. Sehingga dapat diperoleh kesimpulan bahwa hasil diagnosa yang dilakukan oleh pakar sesuai dengan hasil yang dikeluarkan oleh sistem.

\section{B. Pengujian Sistem dengan Sampel Data Kasus}

Penelitian ini memperoleh kasus sebanyak 150 kasus dimana 120 kasus digunakan sebagai basis kasus dan 30 kasus digunakan sebagai data pengujian. Distribusi kasus yang akan diuji berada pada kelas virus, bakteri, dan protozoa. Dimana 12 kasus merupakan kelas virus, 9 kasus kelas bakteri, 7 kasus kelas protozoa, dan 2 kasus belum terdeteksi berada pada kelas mana. Data uji tersebut diperoleh dari sampel data kasus dimana telah diketahui hasil diagnosanya, namun data uji tersebut belum pernah dimasukkan sebagai basis kasus.

Dari Tabel 1 misalkan untuk kasus uji K140 berada pada kelas bakteri, yang mempunyai gejala G3 (sedikit), G12 (ya), G13 (sedikit), dan G14 (cukup). Gejala kasus uji selengkapnya dapat dilihat pada lampiran C. Yang pertama kali dilakukan adalah dengan mencocokan gejala yang diinputkan dengan node gejala yang sudah terbentuk pada pohon keputusannya dimana node awal pada pohon keputusan yang terbentuk adalah G14 kemudian G20, dan node terakhir G12. Karena K140 memiliki G14 dengan nilai cukup maka penelusuran pencarian kelas pada pohon keputusan hanya dilakukan pada node awal yaitu pada G14 yang menunjukkan hasil kelasnya berada pada kelas bakteri. Maka pencarian nilai similarity hanya dilakukan pada kelas bakteri yaitu pada basis kasus ke K51 hingga K85 (lampiran A).

Adapun hasil pengujian 30 kasus dapat dilihat pada Tabel 1. Dari 30 kasus uji, terdapat 28 kasus dengan similaritas diatas 0.8 dan 2 kasus memiliki similaritas kurang dari 0.8 sehingga diperoleh kasus dengan similaritas lebih dari 0.8 sebesar $93.33 \%$ dan kasus dengan similaritas kurang dari 0.8 sebesar $6.67 \%$.

TABEL I.

Hasil Pengujian 30 Kasus Uji

\begin{tabular}{|c|c|c|c|c|c|}
\hline Uji ke & Kasus & "Hasil Diagnosa Penyakit Sebenarnya & "Hasil Diagnosa Penyakit oleh Sistem & Kelas & Nilai Similaritas \\
\hline 1 & K121 & Infectious Bronchitis & Infectious Bronchitis & Virus & 0.98145 \\
\hline 2 & K122 & Infectious Bronchitis & Infectious Bronchitis & Virus & 0.97736 \\
\hline 3 & K123 & Infectious Bronchitis & Infectious Bronchitis & Virus & 0.99425 \\
\hline 4 & K124 & Infectious Bronchitis & Infectious Bronchitis & Virus & 0.97126 \\
\hline 5 & $\mathrm{~K} 125$ & Infectious Bronchitis & Infectious Bronchitis & Virus & 0.96562 \\
\hline 6 & K126 & Avian Influenza & Avian Influenza & Virus & 0.99016 \\
\hline 7 & K127 & Avian Influenza & Avian Influenza & Virus & 0.98552 \\
\hline 8 & K128 & Avian Influenza & Avian Influenza & Virus & 0.99016 \\
\hline 9 & K129 & Avian Influenza & Avian Influenza & Virus & 0.98028 \\
\hline 10 & K130 & Avian Influenza & Avian Influenza & Virus & 0.95320 \\
\hline 11 & K131 & Newcastle Disease & Newcastle Disease & Virus & 0.99164 \\
\hline 12 & K132 & Newcastle Disease & Newcastle Disease & Virus & 0.98757 \\
\hline 13 & K133 & Newcastle Disease & Newcastle Disease & Virus & 0.96269 \\
\hline 14 & K134 & Newcastle Disease & Newcastle Disease & Virus & 0.98934 \\
\hline 15 & K135 & Newcastle Disease & Newcastle Disease & Virus & 0.98288 \\
\hline 16 & K136 & Infectious Bursal Disease & Infectious Bursal Disease & Virus & 0.99358 \\
\hline 17 & K137 & Infectious Bursal Disease & Infectious Bursal Disease & Virus & 0.97198 \\
\hline 18 & K138 & Infectious Bursal Disease & Infectious Bursal Disease & Virus & 0.98809 \\
\hline 19 & K139 & Infectious Bursal Disease & Infectious Bursal Disease & Virus & 0.98378 \\
\hline 20 & K140 & Chronic Respiratory Disease & Chronic Respiratory Disease & Bakteri & 0.92645 \\
\hline 21 & K141 & Chronic Respiratory Disease & Chronic Respiratory Disease & Bakteri & 0.98045 \\
\hline 22 & K142 & Chronic Respiratory Disease & Chronic Respiratory Disease & Bakteri & 0.87940 \\
\hline 23 & K143 & Chronic Respiratory Disease & Chronic Respiratory Disease & Bakteri & 0.98545 \\
\hline 24 & K144 & Infeksius Coryza & Infeksius Coryza & Bakteri & 0.93346 \\
\hline 25 & K145 & Infeksius Coryza & Infeksius Coryza & Bakteri & 0.98425 \\
\hline 26 & K146 & Infeksius Coryza & Infeksius Coryza & Bakteri & 0.95656 \\
\hline 27 & K147 & Koksidiosis & Koksidiosis & Protozoa & 0.86285 \\
\hline 28 & K148 & Koksidiosis & Koksidiosis & Protozoa & 0.89624 \\
\hline 29 & K149 & Infeksius Coryza & Belum Terdeteksi & Belum Terdeteksi & 0 \\
\hline 30 & K150 & Infeksius Coryza & Belum Terdeteksi & Belum Terdeteksi & 0 \\
\hline
\end{tabular}

Dua kasus yang memiliki nilai similaritas kurang dari 0.8 yaitu kasus ke 149 dan 150 dengan nilai similaritas 0 yang kelasnya belum terdeteksi, sehingga kasus tersebut akan dilakukan revisi oleh pakar dan solusinya akan disimpan kembali (retain) ke dalam basis kasus. Sehingga menambah pengetahuan basis kasus pada sistem yang akan digunakan kembali untuk kasus baru berikutnya.

IV.SIMPULAN DAN SARAN

Berdasarkan hasil pengujian Sistem Penalaran Berbasis Kasus Untuk Pendukung Diagnosis Gangguan Penyakit Pada Unggas, maka dapat diambil kesimpulan sebagai berikut :

1. Case-based Reasoning dapat diterapkan pada kasus untuk pendukung diagnosa gangguan penyakit pada unggas. 
2. Metode indexing menggunakan Algoritma C4.5 dapat mempermudah dan mempercepat dalam pencarian similaritas pada kasus baru.

3. Berdasarkan 30 kasus yang diujikan, telah menghasilkan kemiripan sebanyak 28 kasus (93.33 \%) dengan 2 kasus $(6.67 \%)$ mempunyai nilai dibawah 0.8 dan dilakukan revisi oleh pakar.

Diharapkan dalam pengembangan Sistem Penalaran Berbasis Kasus Untuk Pendukung Diagnosis Gangguan Penyakit Pada Unggas adalah :

1. Perlu dilakukan penyimpanan indexing pada Algoritma C4.5 sehingga ketika sistem dijalankan tidak perlu melakukan proses indexing secara berulang kali, karena jika kasus bertambah banyak maka proses indexing akan membutuhkan waktu yang terlalu lama.

2. Perlu dilakukan penelitian terhadap metode indexing selain Algortima C4.5 sehingga dapat diperoleh nilai perbandingan hasil indexing dengan metode-metode lain.

3. Perlu dilakukan penelitian untuk domain penyakit yang lebih kompleks pada penyakit pada unggas. Baik untuk unggas jenis ayam maupun untuk unggas jenis yang lain.

\section{REFERENSI}

[1] Anonim, 2015, Sigap Tanggap Flu Burung di Musim Hujan, Info Medion, Maret 2015, hal. 2.

[2] Berry, Michael J.A. dan Gordon S.Linoff, 2004, Data Mining Techniques for Marketing, Sales, Customer Relationship Management. Second Edition. Wiley Publishing, Inc., Indianapolis, Indiana.

[3] Riesbeck, C. dan Schank, R., 1989, Inside Case-based Reasoning, Lawrence Erlbaum, New Jersey.

[4] Kusrini, 2010, Pemodelan Analisis Diagnosis Banding pada Sistem Pendukung Keputusan Kelompok untuk Asesmen Geriatri, Disertasi, S3 Ilmu Komputer FMIPA UGM, Yogyakarta.

[5] Kusrini dan Luthfi, E. T., 2009, Algoritma Data Mining, Andi Offset, Yogyakarta.

[6] Tan, Pang-Ning, Steinbach, M., Kumar, V., 2006, Introduction to Data Mining, Pearson Education, Inc, Boston. 